\title{
OPEM
}

www.opem.org

Oriental Pharmacy and Experimental Medicine 2009 9(4), 326-334

DOI 10.3742/OPEM.2009.9.4.326

\section{Antinociceptive and gastro-protective effect of the ethanolic extract of the flowering top of Anthocephalus Cadamba Roxb}

\author{
Nusrat Subhan ${ }^{1}$, SM Raquibul Hasan ${ }^{2}$, Md Mokarram Hossain ${ }^{2}$, Raushanara Akter ${ }^{2}$, Muntasir \\ Mamun Majumder ${ }^{2}$, Md Mostafizur Rahman ${ }^{2}$, Kamaluddin Ahmed $^{2}$, Abdul Ghani ${ }^{2}$ and Md \\ Ashraful Alam ${ }^{2, *}$ \\ ${ }^{I}$ Department of Pharmacy, Northern University, Bangladesh; ${ }^{2}$ Pharmacology Laboratory, Department of \\ Pharmacy, Stamford University, 51 Siddeswari Road, Dhaka, Bangladesh
}

Received for publication January 08, 2008; accepted March 20, 2009

\begin{abstract}
SUMMARY
The effect of alcoholic extract of Anthocephalus (A.) Cadamba Roxb. was evaluated in experimental models of pain and ulcer. Hot tail flick test, hot plate test and acetic acid induced writhing test were employed for evaluating the peripheral as well as central analgesic mechanism exerted by the extracts. Gastroprotective activity was examined by $\mathrm{HCl}$ and ethanol induced gastric damage test. Test group received crude extract $500 \mathrm{mg} / \mathrm{kg}$ showed maximum time needed for the response against thermal stimuli $(6.26 \pm 0.439 \mathrm{~s})$ which is comparable to diclofenac sodium $(6.56 \pm$ $0.381 \mathrm{~s}$ ) in hot tail flick method. These experimental results also followed the experimental results of hot plate test where crude extract $500 \mathrm{mg} / \mathrm{kg}$ showed maximum time needed for the response against thermal stimuli $(4.74 \pm 0.234 \mathrm{~s})$ which is comparable to diclofenac sodium $(5.58 \pm 0.585 \mathrm{~s})$. The crude extract at 500 and $250 \mathrm{mg} / \mathrm{kg}$ showed significant reduction in acetic acid induced writhing in mice with a maximum effect of $68.026 \%$ reduction at $500 \mathrm{mg} / \mathrm{kg}$ dose which is comparable to standard diclofenac sodium (79.93\%). In gastroprotective study the extract of $A$. Cadamba (250 and 500 $\mathrm{mg} / \mathrm{kg}$ ) significantly inhibited ulceration induced by both $\mathrm{HCl}$ and ethanol dose dependently. Results of the study suggest that the extract possesses both analgesic and gastroprotective activity on mice.
\end{abstract}

Key words: Anthocephalus Cadamba; Nociceptive pain; NSAID; Diclofenac; Gastric protection

\section{INTRODUCTION}

The use of natural products is growing in the world especially in developing countries. Medicinal herbs have been used as a form of therapy for the relief of pain throughout history (Almeida et al., 2001). The treatment of rheumatic disorder is an area in which the practitioners of traditional medicine enjoy patronage and success (Akah and

*Correspondence: Md Ashraful Alam, Pharmacology Laboratory, Department of Pharmacy, Stamford University, 51 Siddeswari Road, Dhaka, Bangladesh
Nwambie, 1994). Taking into account the most important analgesic prototypes (e.g. salicylic acid and morphine) were originally derived from the plant sources, the study of plant species traditionally used as pain killers should still be seen as a fruitful research strategy in the search of new analgesic and anti-inflammatory drugs. Recent studies found that different substances from plant sources not only afford gastroprotection but also accelerate ulcer healing. They may also possess anti-inflammatory action by suppressing the neutrophil/cytokine cascade in gastrointestinal tract (GIT) (Zayachkivska 
et al., 2005), promoting tissue repair through expression of various growth factors (Kim et al., 2004), exhibiting antioxidant activity (Kim et al., 2004), scavenging reactive oxygen species (ROS) (Liu et al., 2002; Pastrada-Bonilla et al., 2003) showing anti-nucleolytic, cytochome P450 2F1 inhibitory acitivity, anti-necrotic and anti-carcinogenic activities (Bagchi et al., 2002). Anthocephalus (A.) Cadamba Roxb. syn. Anthocephalus chinensis (Family-Rubiaceae) locally known as Kadam is widely distributed throughout Bangladesh, Nepal, eastward to India (Assam Province and Chotanagapur district at Bihar Province), Myanmar, Sri Lanka, the Philippines, Indonesia, and Papua New Guinea (Sahua et al., 2000). It is a large, fast growing species with spreading branches. The tree can reach up to 20 $30 \mathrm{~m}$ in height. In the dry season, the tree sheds its leaves. The tree flowers in May through July. The flowers are yellow in color (Handa et al., 1984a). Plant parts are used as a folk medicine in the treatment of fever and anemia, as antidiuretic, and for improvement of semen quality (Umachigi et al., 2007). The leaves are recommended as a gargle in cases of stomatitis (Slkar et al., 1996). Some scientific studies have been carried out to reveal its antimalarial (Sianne and Fanie, 2002) and antihepatotoxic activities (Kapil et al., 1995). A. Cadamba is ethnomedicinally widely used in the form of paste by tribe in Western Ghats for treating skin diseases. Antibacterial, wound healing and antioxidant properties has also been reported in the recent years (Umachigi et al., 2007). There is little phytochemical information on A. Cadamba. The major constituents of bark are triterpenes, terpernoid glycosides, saponins, indole alkaloids cadambine, 3 a-dihydrocadambine, cadamine, isocadamine and isodihydrocadambine (Handa et al., 1984b; Sahua et al., 2000).

As a part of an investigation on natural bioactive substance from local medicinal plants of Bangladesh, in this paper, we report a study of the antinociceptive and gastroprotective activity of Anthocephalus cadamba flowering tops.

\section{MATERIALS AND METHODS}

\section{Plant material}

The flowering tops of Anthocephalus cadamba (Roxb.) Miq. were collected from Siddeswari campus, Stamford University, Bangladesh in June 2007, and identified by Bangladesh National Herbarium, Mirpur, Dhaka (Accession No.-32497).

\section{Extraction}

Dried ground coarse powder of flowering tops $(200 \mathrm{mg})$ was extracted with $95 \%$ ethanol in a Soxhlet apparatus at an elevated temperature $\left(45^{\circ} \mathrm{C}\right)$. The extract was concentrated by evaporation under reduced pressure at $40^{\circ} \mathrm{C}$ using Buchi rotary evaporator to have gummy concentrate of greenish color extract (yield appx. 6.32\%).

\section{Test samples and standards}

Crude extract of A. Cadamba was prepared in distilled water and was administered at the dose of 250 and $500 \mathrm{mg} / \mathrm{kg}$ body weight per orally. Diclofenac sodium $(100 \mathrm{mg} / \mathrm{kg})$ was used as standard in antinociceptive tests. $\mathrm{HCl}$ and ethanol were used to produce damage to gastric mucosa in gastroprotective test. Gastric administration of all drugs was accomplished via oral gavages by feeding needle.

\begin{abstract}
Animal
Male Swiss albino mice (20 - $25 \mathrm{~g})$ were used in this investigation. Albino mice were obtained from the Animal house of the International Centre for Diarrhoeal Disease and Research, Bangladesh (ICDDR, B). Animals were maintained under standard environmental conditions and had free access to feed and water ad libitum. Experiments on animals were performed based on animal ethics guidelines (Zimmermann, 1983) and approved by Institutional Animal Research Ethics Committee. Albino mice ( $n=5$, per group) were used for antinociceptive activity screening and divided into four different groups. First group served as control animals they were treated with distilled water.
\end{abstract}


Second group of animals were treated with standard drugs. The standard drugs diclofenac sodium 100 $\mathrm{mg} / \mathrm{kg}$ (anti-nociceptive activity) was used. The next two groups of animal were treated with the alcoholic crude extract at two different doses (250 and $500 \mathrm{mg} / \mathrm{kg}$ ). In ethanol and $\mathrm{HCl}$ induced mucosal damage study similar mice $(n=5$, per group) were divided into six groups. First two groups serve as control groups, next two groups were treated with $250 \mathrm{mg} / \mathrm{kg}$ extract and the last two groups with $500 \mathrm{mg} / \mathrm{kg}$ extract. One hour after administration of ethanol and $\mathrm{HCl}$, each animal was killed by ether anesthesia and the stomach was removed and inflated by injection of $10 \mathrm{ml} \mathrm{1.5 \%}$ formalin to fix the inner and outer layers of the gastric walls. Subsequently, the stomach was incised along the greater curvature; the lengths and numbers of gastric lesions were measured and were expressed as a lesion index.

\section{Writhing test}

The 'acetic acid' test method used in this study was adopted from those described in detail earlier by Hendershot and Forsaith, (1959), Koster et al. (1959), Williamson et al. (1996), Zakaria et al. (2001) and Silva et al. (2003). Experimental animals were randomly selected and divided into four groups denoted as group-I, group-II, group-III, group-IV, consisting of 5 mice in each group. Each group received a particular treatment i.e. control, positive control and the two doses of the extract. Group-I is served as the control and received only distilled water and tween-80. Group-II was received diclofenac sodium $(100 \mathrm{mg} / \mathrm{kg}$, i.p), administered $15 \mathrm{~min}$ prior to counting of writhings, the standard drug for comparison of potencies. The last two groups i.e. Group-III and Group-IV were administered the crude extract suspensions orally. $30 \mathrm{~min}$ interval was given to ensure proper absorption of the administered substances. Then each group was treated with intraperitoneally administered $0.2 \mathrm{ml}$ of a $0.6 \%$ acetic acid solution (Koster et al., 1959). The number of writhes (i.e., abdominal contractions and stretches) that occurred within the first $20 \mathrm{~min}$ following acetic acid administration were counted and recorded. The recorded numbers of acetic acid-induced writhes that occurred in the positive control and test group i.e. crude extracts treated mice were compared with those in the control group mice.

\section{Hot plate test}

The hot plate test was carried out according to the method described by Woolfe and Mac Donald (1944). Mice were placed on a hot plate maintained at $55^{\circ} \mathrm{C} \pm 1^{\circ} \mathrm{C}$. Latency of nociceptive response such as licking of a hind limb or jumping was measured. Starting $30 \mathrm{~min}$ after oral administration of the test agents except diclofenac- sodium (15 min after administration), the nociceptive response was measured every $30 \mathrm{~min}$ over a $90 \mathrm{~min}$ period. Diclofenac sodium was injected intraperitoneally. The cut-off time was $15 \mathrm{~s}$. Only the mice that showed nociceptive responses within $10 \mathrm{~s}$ were used for the experiments.

\section{Tail flick test}

Mice were treated with distilled water, diclofenac sodium $(100 \mathrm{mg} / \mathrm{kg})$ and two doses of the crude extract $(250$ and $500 \mathrm{mg} / \mathrm{kg}$ ). Antinociceptive effect of the test substances was determined by the hot tail-flick method described by Sewell and Spencer (1976). Basal reaction time of animals to radiant heat was recorded by placing the tip (last $1-2 \mathrm{~cm}$ ) of the tail on the radiant heat source. The tail withdrawal from the heat (flicking response) is taken as the end point. The animals, which showed flicking response within $3-5 \mathrm{~s}$, were selected for the study. A cut off period of $15 \mathrm{~s}$ is observed to avoid damage to the tail. The measurements of withdrawal time using the tail flick apparatus was conducted at 30 and $60 \mathrm{~min}$ after administration of drugs.

$\mathrm{HCl}$ and ethanol-induced mucosal membrane lesions Gastric mucosal lesions were induced by the method 
of Mizui and Doteuchi (1983). The mice were divided into groups of 5 animals. After $24 \mathrm{~h}$ fasting, the extracts and drugs were administered orally to the mice. $30 \mathrm{~min}$ thereafter, each mouse received $0.2 \mathrm{ml}$ of $1 \mathrm{~N} \mathrm{HCl}$ or absolute ethanol by oral administration. $60 \mathrm{~min}$ after administration of the necrotizing agent, each animal was killed by ether euthanasia, and the stomach was excised, inflated by injecting $2 \mathrm{ml}$ of normal saline and then fixed for $30 \mathrm{~min}$ in $5 \%$ formalin solution. After opening along the greater curvature, $\mathrm{HCl}$ induced gastric damage was observed in the gastric mucosa as elongated black-red lines parallel to the long axis of the stomach of the mice. The lesion index was determined as the sum or length of erosion per mouse (Sun et al., 1991). Ethanol induced lesion was assessed and scored for severity according to, (0) absence of lesion, (1) superficial 1 - 5 hemorrhagic points, (2) superficial 6 - 10 hemorrhagic points, (3) submucosal hemorrhagic lesions with small erosions (4) severe hemorrhagic lesion and some invasive lesions.

\section{Statistical analysis}

Results were expressed as mean \pm S.E.M. and were analyzed for statistically significant difference using one-way ANOVA, followed by the Bonferroni posthoc test. $P$ values $<0.05$ were considered significant.

\section{RESULTS}

Analgesic activity was determined by evaluating the response against a series of experimental animal model like hot plate test; hot tail flick test, writhing effect which was produced by administration of the acetic acid by the test drug i.e. crude extracts in comparison with a standard drug might prove efficacy of the desired action.

\section{Acetic acid-induced writhing test}

Dose dependent antinoceceptive effect was noted with the extract at the tested dose levels (Table 1). Maximum percentage of inhibition of writhing response exhibited by the extract at $500 \mathrm{mg} / \mathrm{kg}$ was $68.026 \%$, while the same at $250 \mathrm{mg} / \mathrm{kg}$ showed $40.133 \%$ reduction in acetic acid induced writhing response respectively, which was comparable to that of standard diclofenac sodium $(100 \mathrm{mg} / \mathrm{kg})$ that caused $79.93 \%$ pain inhibition.

\section{Hot plate test}

Two doses of extracts of $A$. Cadamba increased the reaction time in a dose-dependent manner to the thermal stimulus which is presented in the Table 2 . The highest nociceptive inhibition of thermal stimulus was exhibited at a higher dose of the extracts 500 $\mathrm{mg} / \mathrm{kg}$ of crude extract which has maximum time needed for the response against thermal stimuli $(4.74 \pm 0.225)$, which is comparable to diclofenac sodium $(5.58 \pm 0.585)$.

\section{Tail immersion/hot tail-flick}

Table 3 shows the results of the Tail immersion/ hot tail-flick test results. Two doses of extracts of $A$. Cadamba increased the reaction time in a dosedependent manner to the thermal stimulus. The highest nociceptive inhibition of thermal stimulus was exhibited at a higher dose of the extracts 500

Table 1. Effect of A. Cadamba ethanolic extract on acetic acid induced writhing in mice

\begin{tabular}{lccccc}
\hline Treatment & $\begin{array}{c}\text { Dose } \\
(\mathrm{mg} / \mathrm{kg})^{\mathrm{a}}\end{array}$ & $\begin{array}{c}\text { Route of } \\
\text { administration }\end{array}$ & Writhings $^{\mathrm{b}}$ & \% of writhing & $\begin{array}{c}\text { \% of writhing } \\
\text { Inhibition }\end{array}$ \\
\hline Control (Distilled water) & $10 \mathrm{ml} / \mathrm{kg}$ & p.o. & $29.9 \pm 1.303$ & 100 & $0 \%$ \\
Diclofenac-Na & 100 & i.p. & $6.1 \pm 0.314^{*}$ & 20.06 & $79.93 \%$ \\
A. Cadamba Extract & 250 & p.o. & $17.9 \pm 0.758^{*}$ & 59.86 & $40.133 \%$ \\
& 500 & p.o & $9.56 \pm 0.733^{*}$ & 31.97 & $68.026 \%$ \\
\hline
\end{tabular}

${ }^{a}$ Administered $30 \mathrm{~min}$ before $0.2 \mathrm{ml}$ of $0.6 \%$ acetic acid administration $\left(10 \mathrm{ml} / \mathrm{kg}\right.$, i.p.). ${ }^{\mathrm{b}}$ Counted for $20 \mathrm{~min}$, starting 5 min after acetic acid administration; ${ }^{*} P<0.05$ vs. control, Student's t-test; values are mean \pm S.E.M. $(n=5)$. 
Table 2. Effect of A. Cadamba ethanolic extracts on hot plate test in mice

\begin{tabular}{lccrrr}
\hline \multirow{2}{*}{ Treatment } & Dose & \multicolumn{4}{c}{ Response Time (s) } \\
\cline { 3 - 6 }$(\mathrm{mg} / \mathrm{kg}, \mathrm{p} . \mathrm{o})^{\mathrm{a}}$ & $0 \mathrm{~min}$ & $30 \mathrm{~min}$ & $60 \mathrm{~min}$ & $90 \mathrm{~min}$ \\
\hline Control (Distilled water) & $10 \mathrm{ml} / \mathrm{kg}$ & $1.78 \pm 0.263$ & $2.5 \pm 0.187$ & $2.9 \pm 0.370$ & $3.08 \pm 0.451$ \\
Diclofenac-Na & 100 (i. p.) & $1.98 \pm 0.198$ & $4.72 \pm 0.435^{*}$ & $4.94 \pm 0.577^{*}$ & $5.58 \pm 0.585^{*}$ \\
A. Cadamba Extract & 250 & $2.04 \pm 0.288$ & $3.88 \pm 0.451^{*}$ & $4.06 \pm 0.386^{*}$ & $4.2 \pm 0.206^{*}$ \\
& 500 & $2.08 \pm 0.163$ & $4.8 \pm 0.254^{*}$ & $4.7 \pm 0.234^{*}$ & $4.74 \pm 0.225^{*}$ \\
\hline
\end{tabular}

${ }^{a}$ Beginning $30 \mathrm{~min}$ after oral administration of test agents (or $15 \mathrm{~min}$ after Diclofenac-Na.), the nociceptive response was measured every $30 \mathrm{~min}$ over a 90 -min period. Each datum represents the latency of nociceptive responses $(\mathrm{s}) \pm$ S.E.M. $(\mathrm{n}=5)$. ${ }^{*} P<0.05$ compared with the control group (Student's $t$-test)

Table 3. Effect of A. Cadamba ethanolic extracts on hot tail -flick test in mice

\begin{tabular}{lcccc}
\hline \multirow{2}{*}{ Treatment } & Dose & \multicolumn{3}{c}{ Response Time (sec) } \\
\cline { 2 - 5 } & $(\mathrm{mg} / \mathrm{kg}, \mathrm{p} . \mathrm{o})^{\mathrm{a}}$ & $0 \mathrm{~min}$ (Latency) & $30 \mathrm{~min}$ & $60 \mathrm{~min}$ \\
\hline Control (Distilled water) & $10 \mathrm{ml} / \mathrm{kg}$ & $2.2 \pm 0.418$ & $2.64 \pm 0.749$ & $2.6 \pm 0.273$ \\
Diclofenac-Na & 100 (i.p.) & $4.2 \pm 0.418^{*}$ & $4.69 \pm 0.329^{*}$ & $6.56 \pm 0.381^{*}$ \\
A. Cadamba extracts & 250 & $2.4 \pm 0.447$ & $4.9 \pm 0.245^{*}$ & $4.934 \pm 0.616^{*}$ \\
& 500 & $2.8 \pm 0.418$ & $5.26 \pm 0.460^{* *}$ & $6.26 \pm 0.439^{*}$ \\
\hline
\end{tabular}

${ }^{a}$ Beginning $30 \mathrm{~min}$ after oral administration of test agents (or $15 \mathrm{~min}$ after Diclofenac-Na.), the nociceptive response was measured every $30 \mathrm{~min}$ over a $60 \mathrm{~min}$ period. Each datum represents the latency of nociceptive responses (s) \pm S.E.M. $(n=5) * P<0.05$ compared with the control group (Student's $t$-test)

Table 4. Ulcer protective effect of the ethanolic extract of $A$. Cadamba

\begin{tabular}{lcccr}
\hline \multirow{2}{*}{ Treatment } & Dose & Route of & \multicolumn{2}{c}{ Ulcer Score } \\
\cline { 4 - 5 }$(\mathrm{mg} / \mathrm{kg})$ & administration & $\mathrm{HCl}(\mathrm{mm})$ & \multicolumn{1}{c}{ Absolute ethanol } \\
\hline Control 1 N HCL or & $0.2 \mathrm{ml}$ & p.o. & $15.6 \pm 0.758$ & $11.6 \pm 0.908(2.31,100 \%)$ \\
Absolute ethanol & & & & \\
A. Cadamba extracts & 250 & p.o. & $10.8 \pm 0.651^{*}$ & $6.00 \pm 0.612^{*}(1.2 ; 51.724 \%)$ \\
& 500 & p.o & $5.2 \pm 0.418^{*}$ & $4.2 \pm 0.418^{*}(0.84 ; 6.206 \%)$ \\
\hline
\end{tabular}

Data represents the mean \pm S.E.M., ${ }^{*} P<0.05$ compared with the control considered as statistically significant. Ulcer score was determined in case of $\mathrm{HCl}$ induced lesion as lengtn/mouse and score of ethanol induced lesion was calculated as the number of ulcer spot found per mouse.

$\mathrm{mg} / \mathrm{kg}$ of crude extract $(6.26 \pm 0.439)$, which is comparable to that of diclofenac sodium $(6.56 \pm$ $0.381)$.

\section{$\mathrm{HCl}$ or ethanol-induced mucosal membrane lesions}

The extract of A. Cadamba $(250-500 \mathrm{mg} / \mathrm{kg}$ ) significantly $(P<0.05)$ inhibited ulceration induced by both $\mathrm{HCl}$ and ethanol dose dependently in mice. The results obtained were compared with the control group animals which received no treatment other than exposed to $\mathrm{HCl}$ or ethanol orally (Table 4 and Fig. 1).

\section{DISCUSSION}

The results demonstrate that the ethanol extract obtained from the flowering tops of A. Cadamba attenuated centrally acting pain mechanism as well as nociceptive responses to chemical stimuli in the acetic acid induced writhing in mice.

The writhing test is generally used for screening of antinociceptive effects (Hendershot and Forsaith, 1959; Koster et al., 1959). With respect to the writhing test, the research group of Deraedt et al. (1980) 


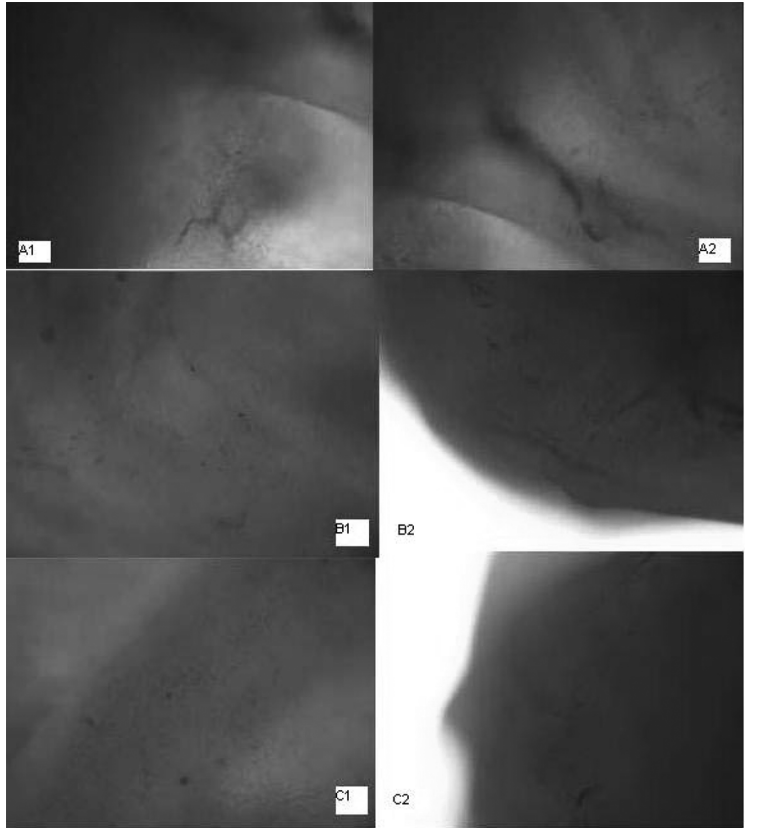

Fig. 1. Typical photomicrograph of the ulcer induced by ethanol and $\mathrm{HCl}$. A1, A2- Untreated control group for $\mathrm{HCl}$ and ethanol; B1, B2- A. Cadamba extract (250 $\mathrm{mg} / \mathrm{kg})+1 \mathrm{~N} \mathrm{HCl}$ acid or Ethanol; C1, C2- A. cadamba extract $(500 \mathrm{mg} / \mathrm{kg})+1 \mathrm{~N} \mathrm{HCl}$ acid or ethanol. (Binocular microscope Axistar Plus with cannon A 610/620 photo documentation system, Magnification $\times 10$ ).

described the quantification of prostaglandins by radioimmunoassay in the peritoneal exudates of rats, obtained after intraperitoneal injection of acetic acid. They found high levels of prostaglandins PGE2a and PGF2a during the first $30 \mathrm{~min}$ after acetic acid injection. Nevertheless, it was found that the intraperitoneal administration of acetic acid induces the liberation not only of prostaglandins, but also of the sympathetic nervous system mediators (Hokanson, 1978; Duarte et al., 1988). The ethanol extracts of $A$. Cadamba showed significant inhibition on acetic acid-induced writhing response compared to reference drug diclofenac sodium $(100 \mathrm{mg} / \mathrm{kg})$ in mice. Diclofenac, a non-steroidal anti-inflammatory drug (NSAID), is commonly employed in the treatment and/or management of rheumatoid arthritis, osteo-arthritis and ankylosing spondylitis (Eddy and Leimback, 1953; Siraux,
1977) and for its anti-inflammatory and analgesic effects (Brooks et al., 1980). Diclofenac reduces inflammation, swelling and arthritic pain by inhibiting prostaglandins synthesis and/or production (Skoutakis et al., 1988; Todd and Sorkin, 1988; Small, 1989).

It is known that non-steroidal anti-inflammatory drugs usually do not increase the pain threshold in normal tissues, whereas local anesthetics and narcotics do (Ferreira et al., 1978). Hence, the hot plate test and hot-tail flick test was undertaken to verify whether the ethanol extract of $A$. Cadamba have any central analgesic effect. Thermic painful stimuli are known to be selective to centrally but not peripherally acting analgesic drugs (Chau, 1989). Thermal induced nociception indicates narcotic involvement (Besra et al., 1996) and are more sensitive to opioid $\mu$ receptors and non-thermal tests are to opioid $\kappa$ receptors. (Abbott and Young, 1988) The centrally acting analgesics generally elevate the pain threshold of mice towards heat. Ethanolic extract of $A$. Cadamba significantly $(P<0.05)$ increased the reaction time of animals towards the thermal source in a dose-dependent manner. In hot plate test 500 $\mathrm{mg} / \mathrm{kg}$ dose of ethanolic extract of A. Cadamba showed a pain inhibition by increasing the reaction time (licking of paw) from $2.08 \pm 0.163 \mathrm{~s}$ to $4.74 \pm$ $0.225 \mathrm{~s}$ after $90 \mathrm{~min}$ of the dose administered whereas the standard drug diclofenac showed a pain inhibition by increasing the reaction time (licking of paw) from $1.98 \pm 0.198 \mathrm{~s}$ to $5.58 \pm 0.585 \mathrm{~s}$ (Table 2). Ethanolic extract of A. Cadamba $250 \mathrm{mg} / \mathrm{kg}$ dose also significantly increase the reaction time.

The drugs showed greater activity after $60 \mathrm{~min}$ of drug administration, in which ethanolic extract of $A$. Cadamba ( $500 \mathrm{mg} / \mathrm{kg}$, p. o.) exhibited greater pain inhibition by increasing the reaction time (licking of tail from hot water) from $2.8 \pm 0.418 \mathrm{~s}$ to $6.26 \pm 0.439 \mathrm{~s}$ (Table 3) in Tail flick test. The results for the group-treated with the ethanol extracts of $A$. Cadamba significantly inhibit the central pain mechanism from those obtained for the negative control group. Thus the anti-nociceptive activity shown by crude extract of A. Cadamba in hot plate, 
hot tail-flick and acetic acid induced writhing test indicate that alcoholic extracts of the plant might possess centrally and peripherally mediated antinociceptive properties.

Gastric mucosal layers play a role of a barrier that limits the exposure of the gastric mucosal cells to numerous injurious luminal agents and irritants of exogenous and endogenous origin (Zayachkivska et al., 2005). Mucosal surface epithelium is a subject of attack by physical, chemical or microbiological agents acting from the gastric lumen, which are involved in multiple pathologies, such as gastritis, peptic ulcer or gastric cancer. Pretreatment with different substances could effectively prevent gastric mucosa from the development of erosions and ulcerations. This action is called gastro- or cytoprotection. There are various plant-originated "gastroprotectors" with different composition that have been used in clinical and folk medicine for many countries due to their beneficial effects on the mucosa of GIT. In China and Japan, polyphenol extracts such as Sopharadin extracts, containing flavonoids and its synthetic flavonoid derivative known as Solon are widely employed in peptic ulcer therapy and also as food additives and nutritional supplements, mainly because of their strong inhibition of prostaglandin (PG) metabolism and vasoconstrictive leukotriene inhibition (Zayachkivska et al., 2005).

Inhibition of ethanol induced gastric lesion indicates a promising antiulcerogenic activity of the extract and suggested that an antisecretory or cytoprotective action may be involved (Morimoto et al., 1991). It is possible that the inhibitory effects of extracts are due, at least partly, to the presence of terpenes (Alvarez et al., 1999; Gonzales et al., 2000). Terpenes were found to be associated with antiulcerogenic activity in other plants (Moehle $e t$ al., 1985; Mahran et al., 1992). Some triterpenes are known as antiulcer drugs and their action has been suggested to be due to the activation of cellular protection, reduction of mucosal prostaglandins metabolism-cytoprotective action, reduction of gastric vascular permeability and stimulation of mucus secretion (Lewis and Hanson, 1991; Sertié et al., 2000). Flavonoids also have antiulcer and gastroprotective activities (Mizui and Doteuchi, 1983; Sun et al., 1991; Sertié et al., 2000). The aqueous extracts of Phoradendron crassifolium and Franserio artemisiodes that contain polyphenolic agents exerted cytoprotective activity in rats (Gonzales et al., 2000). Two flavonoids have been isolated from $\mathrm{A}$. graveolens seed, quercetin 3-Obeta-D-glucuronide and isoharmentin 3-O-beta-Dglucuronide, have antioxidant activity and could counteract with free radicals. This effect may help to prevent ulcer peptic (Moehle et al., 1985, Mahran et al., 1992). The dose dependent reduction in $\mathrm{HCl}$ or absolute ethanol induced ulceration by the ethanolic extract of A. Cadamba probably suggests the presence of some active ingredients possibly triterpenes which act through one or more ulcer protecting mechanisms.

In this investigation the extract showed both significant centrally and peripherally acting antinociceptive activity and gastroprotective activity. Though peripherally mediated antinociceptive activity is thought to be closely related to prostaglandin inhibition, triterpenes present in the extract at the same time protects the gastric mucosa probably by maintaining normal level of prostaglandin in stomach and stimulating mucus secretion i.e. the extract can be used as a novel analgesic that rather than damaging gastric mucosa, protects it.

The ability of the extracts to suppress abdominal writhes, increase pain threshold latency, suppression of the $\mathrm{HCl}$ or Ethanol induced inflammation confirms the analgesic and anti-ulcerative properties of the extract. These findings justify traditional use of this plant in the treatment of pain and other inflammatory conditions and validate its claim of being used for the said purpose in folklore medicine. It can be concluded that alcoholic extracts of $A$. Cadamba possesses analgesic properties, which are probably mediated via inhibition of prostaglandin 
synthesis as well as central inhibitory mechanisms which may be of potential benefit for the management of pain where ulceration is a problem with NSAID therapy. Further research should be necessary for elucidating the active principle as well as toxicological studies.

\section{REFERENCES}

Abbott F, Young SN. (1988) Effect of 5-hydroxy tryptanin precursors on morphine analgesia in the formalin test. Pharmacol. Biochem. Behav. 31, 855-860.

Akah PA, Nwambie AI. (1994) Evaluation of Nigerian traditional medicines: plants used for rheumatic disorder. J. Ethnopharmacol. 42, 179-182.

Almeida RN, Navarro DS, Barbosa-Filho JM. (2001) Plants with central analgesic activity. Phytomedicine 8, 310-322.

Alvarez A, Pomar F, Sevilla MA, Montero MJ. (1999) Gastric antisecretory and antiulcer activities of an ethanolic extract of Bidens pilosa L. var. radiata Schult. Bip. J. Ethnopharmacol. 67, 333-340.

Bagchi D, Ray SD, Bagchi M, Preuss HG, Stohs SJ. (2002) Mechanistic pathways of antioxidant cytoprotection by a novel IH636 grape seed proanthocyanidin extract. Indian J. Exp. Biol. 40, 717726.

Besra SE, Sharma RM, Gomes A. (1996) Antiinflammatory effect of petroleum ether extract of leaves of Litchi chinensis Gaertn (Sapinadaceae). J. Ethnopharmacol. 54, 1-6.

Brooks P.M, Hill W, Geddes R. (1980) Diclofenac and ibuprofen in rheumatoid arthritis and osteoarthritis. Med. J. Aus. 1, 29-30.

Chau T. (1989) Pharmacology methods in the control of inflammation. In: Modern Methods in Pharmacology 5, 195-212.

Deraedt R, Jouquey S, Delevallee F, Flahaut M. (1980) Release of prostaglandins $\mathrm{E}$ and $\mathrm{F}$ in an algogenic reaction and its inhibition. Eur. J. Pharmacol. 61, 17-24.

Duarte JDG, Nakamura M, Ferreira SH. (1988) Participation of the sympathetic system in acetic acid induced writhing in mice. Brazilian J. Med. Biol. Res. 21, 341-343.

Eddy ND, Leimback D. (1953) Synthetic analgesics: II. Dithyienylbutenylamines and dithyienylbutylamines.
J. Pharmacol. Exp. Ther. 3, 544-547.

Ferreira SH, Lorenzetti BB, Castro MSA, Correa FMA. (1978) Antialgic effect of aspirin-like drugs and the inhibition of prostaglandin synthesis. In: Dumonde, D.C., Jasani, M.K. (Eds.), The Recognition of Antirheumatic Drugs. MTP Press Limited St. Leonard House Lancaster 25-37.

Gonzales E, Iglesias I, Carretero E, Villar A. (2000) Gastric cytoprotection of Bolivian medicinal plants. J. Ethnopharmacol. 70, 329-333.

Handa SS, Borris RP, Cordell GA. (1984a) NMR spectral analysis of cadambine from Anthocephalus chinensis. J. Nat. Prod. 46, 325-330.

Handa SS, Gupta SK, Vasisht K, Keene AT, Phillipson JD. (1984b) Quinoline alkaloids from Anthocephalus chinensis. Planta Med. 50, 358.

Hendershot LC, Forsaith J. (1959) Antagonism of the frequency of phenylquinone-induced writhing in the mouse by weak analgesics and nonanalgesics. J. Pharmacol. Exp. Ther. 125, 237-240.

Hokanson GC. (1978) Acetic acid for analgesic screening. J. Nat. Prod. 41, 497-498.

Kapil A, Koul I, Suri OP. (1995) Antihepatotoxic effects of chlorogenic acid from Anthocephalus cadamba. Phytother. Res. 9, 189-193.

Kim SC, Byun SH, Yang CH, Kim CY, Kim JW, Kim SG. (2004) Cytoprotective effects of Glycyrrhizae radix extract and its active component liquiritigenin against cadmium-induced toxicity (effects on bad translocation and cytochrome c-mediated PARP cleavage). Toxicology 197, 239-251.

Koster R, Anderson M, de Beer EJ. (1959) Acetic acid for analgesic screening. Fed. Proc. 18, 412.

Lewis DA and Hanson PJ (1991). Anti-ulcer drugs of plant origin. In: Ellis, G. P., G.B. (Eds.), Progress Medicinal Chemistry, Elsevier Science Publishers, Amsterdam v. 28, 201-231.

Liu CF, Lin CC, Lin MH, Lin YS, Lin SC. (2002) Cytoprotection by propolis ethanol extract of acute absolute ethanol-induced gastric mucosal lesions. Am. J. Chin. Med. 30, 245-254.

Mahran GH, Kadry HA, Thabet CK, Al-Azizi MM, Liv N. (1992) GC/MS analysis of volatile oil of fruits of Anethum graveolens. Int. J. Pharmacog. 30, 139-144.

Mizui T, Doteuchi M. (1983) Effect of polyamines on acidified ethanol-induced gastric lesions in rats. Jpn. 
J. Pharmacol. 33, 930-945.

Moehle B, Heller W, Wellmann E. (1985) UV-induced biosynthesis of quercetin 3-o-beta-d-glucuronide in dill Anethum graveolens cell cultures. Phytochemistry 24, 465-468.

Morimoto Y, Shimohara K, Oshima S, Sukamoto T. (1991). Effects of the new anti-ulcer agent KB-5492 on experimental gastric mucosal lesions and gastric mucosal defensive factors, as compared to those of teprenone and cimetidine. Jpn. J. Pharmacol. 57, 495505.

Pastrada-Bonilla E, Akoh CC, Sellappan S, Krewer G. (2003) Phenolic content and antioxidant capacity of muscadine grapes. J. Agri. Food Chem. 51, 5497-5503.

Sahua NP, Koike K, Jia Z, Banerjee S, Mandal NB, Nikaido T. (2000). Triterpene glycosides from the bark of Anthocephalus cadamba. J. Chem. Res. 1, 22-23.

Sertié JAA, Carvalho JCT, Panizza S. (2000) Antiulcer activity of the crude extract from the leaves of Casearia sylvestris. Pharmac. Biol. 38, 112-119.

Sewell RDE, Spencer PSJ. (1976). Antinociceptive activity of narcotic agonist and partial agonist analgesics and other agents in the tail-immersion test in mice and rats. Neuropharmacology 15, 23-29.

Sianne Schwikkard and Fanie R. van Heerden. (2002). Antimalarial activity of plant metabolite. Nat. Prod. Rep. 19, 675-692.

Silva J, Abebe W, Sousa SM, Duarte VG, Machado MI, Matos FJ. (2003) Analgesic and anti-inflammatory effects of essential oils of eucalyptus. J. Ethnopharmacol. 89, 277-83.

Siraux P. (1977) Diclofenac (voltaren ${ }^{\circledR}$ ) for the treatment of osteoarthritis: a double-blind comparison with naproxen. J. Int. Med. Res. 5, 169-174.

Skoutakis VA, Carter CA, Mickle TR, Smith VH, Arkin CR, Alissandratos J, Pretty DE. (1988) Review of diclofenac and evaluation of its place in therapy as a non-steroidal anti-inflammatory agent. Drug
Intellig. Clin. Pharm. 22, 805-859.

Slkar IV, Kakkar KK, Chakre OJ. (1992) Glossary of Indian Medicinal Plants with Active Principles. CSIR, New Delhi 1, 75.

Small RE. (1989) Drug reviews: diclofenac sodium. Clin. Pharm. 8, 545-558.

Sun X-B, Matsumoto T, Kiyohara H. (1991) Cytoprotective activity of peptic polysaccharides from the root of Panax ginseng. J. Ethnopharmacol. 31, 101-107.

Todd PA, Sorkin EM. (1988) Diclofenac sodium: a reappraisal of its pharmacodynamic and pharmacokinetic properties and therapeutic efficacy. Drugs 35, 244285.

Umachigi SP, Kumar GS, Jayaveera KN, Kishore Kumar DV, Ashok Kumar CK, Dhanapal R. (2007) Antimicrobial, wound healing and antioxidant activities of anthocephalus Cadamba. Afr. J. Trad. CAM. 4, 481-487.

Williamson EM, Okpako DT, Evans FJ. (1996) Pharmacological methods in phytotherapy research. In: Selection, Preparation and Pharmacological Evaluation of Plant Materials, Vol. 1. John Wiley, Chichester, 184-186.

Woolfe G, MacDonald AD. (1944) The evaluation of the analgesic action of pethidine hydrochloride (Demerol). J. Pharmacol. Exp. Ther. 80, 300-330.

Zakaria MN, Islam MW, Radhakrishnan R, Chen HB, Kamil M, Al-Gifri AN, Chan-Attas A. (2001) Antinociceptive and anti-inflammatory properties of Caralluma arabi. J. Ethnopharmacol. 76, 155-158.

Zayachkivska OS, Konturek SJ, Drozdowicz D, Konturek PC, Brzozowski T, Ghegotsky MR. (2005) Gastroprotective effects of flavonoids in plant extracts. J. Physiol. Pharmacol. 56, 219-231.

Zimmermann M. (1983) Ethical guidelines for investigations on experimental pain in conscious animals. Pain 16, 109-111. 